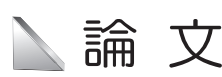

Original Paper

\section{バイオグラウト処理された地盤材料を用いた 間隙率評価手法に関する検討 *}

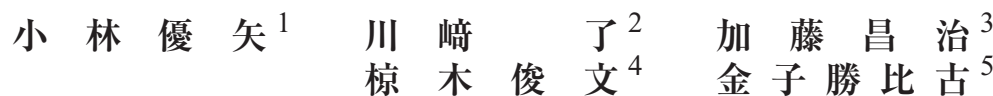

\title{
Applicability of a Method for Evaluation of Porosity to Biogrouted Geomaterials
}

\author{
Yuya KOBAYASHI ${ }^{\mathrm{a}}$, Satoru KAWASAKI ${ }^{\mathrm{b}}$, Masaji $\mathrm{KATO}^{\mathrm{c}}$, \\ Toshifumi MUKUNOKI ${ }^{\mathrm{d}}$ and Katsuhiko KANEKO
}

a. Graduate student, Division of Field Engineering for Environment, Graduate School of Engineering, Hokkaido University, Sapporo 060-8628, JAPAN

(Corresponding author E-mail: ykobayashi@geo-er.eng.hokudai.ac.jp)

b. Associate Professor, Division of Field Engineering for Environment, Graduate School of Engineering, Hokkaido University

c. Assistant Professor, Division of Field Engineering for Environment, Graduate School of Engineering, Hokkaido University

d. Associate Professor, Department of Civil and Environmental Engineering, Graduate School of Science and Technology, Kumamoto University, Kumamoto 860-8555, JAPAN

e. Professor, Division of Field Engineering for Environment, Graduate School of Engineering, Hokkaido University

\begin{abstract}
This study considers a method for evaluation of porosity of biogrouted geomaterials. First, we visualized the internal structures of the specimens by using micro-focused X-ray CT scanner. We tested Souma sand, gum tips, plastic pellets, steel balls and glass beads as geomaterial to find suitable geomaterials for evaluation of porosity: geomaterials whose CT-number histogram was bimodal. The results clarified that one of the geomaterials, glass beads whose particle size was $0.50-0.71 \mathrm{~mm}$, was suitable for evaluation of porosity. Second, we calculated the porosity of the glass beads by using a method for evaluation of porosity based on a maximum likelihood thresholding method considering the effect of mixels. The result showed that the ratio of the porosity of grouted geomaterial to that of ungrouted geomaterial was 0.98 to 0.99 . On the other hand, the value estimated by the measurement of changes in concentration of calcium ion was 0.98 . Thus, both values closely agreed. Therefore, this study clarifies that the method enables us to evaluate small change in porosity with great accuracy.
\end{abstract}

KEY WORDS: Porosity, Threshold, Mixel, Biogrout, X-ray CT

\section{1.は じめに}

地盤や岩盤の間隙率は，それらの供試体全体の体積に占める間 隙体積の割合として定義される。それは，供試体の内部を定量的 に特徵づける物理的性質を示すパラメータの一つであり, その評 価は重要である。

*2009 年 7 月 6 日受付 2009 年 9 月 30 日受理

1. 学生会員 学士 (工) 北海道大学大学院工学研究科環境フィールド工 学専攻 修士課程学生

2. 普通会員博士 (工) 北海道大学大学院工学研究科環境フィールド工 学専攻 准教授

3. 普通会員 学士 (工) 北海道大学大学院工学研究科環境フィールド工 学専攻 助教

4. 普通会員博士 ( 工) 熊本大学大学院自然科学研究科社会環境工学専 攻 准教授

5. 普通会員 工学博士 北海道大学大学院工学研究科環境フィールド工学 専攻 教授

[ 著者連絡先 ] FAX: 011-706-6325

E-mail: ykobayashi@geo-er.eng.hokudai.ac.jp

キーワード : 間隙率, 閾值，ミクセル，バイオグラウト，X 線 CT
バイオグラウト 1) の研究分野においても，以下に述べる理由 でその評価は重要である。バイオグラウトとは，地盤や岩盤中に 生息する微生物の代謝活動を利用し，炭酸カルシウムやシリカを 地盤や岩盤中に析出・固化させ，地盤の間隙や岩盤の亀裂を閉塞 させるものであり，地盤や岩盤の改良工法の一つとして，現在， 国内外で研究が進められている ${ }^{2-4)}$ 。こで，炭酸カルシウムを 主材料としたバイオグラウトに関する既往の研究について言及す ると, バイオグラウト処理された供試体 ( 以下, バイオグラウト 供試体）の強度が期待される值に達していない5)。したがって, 炭酸カルシウムの析出量の増加によるバイオグラウト供試体の強 度の向上が現在の研究課題の一つとなっている。炭酸カルシウム の析出量について論じるためには, まず, 炭酸カルシウムの析出 量の定量的な把握が必要となる。そして, その定量的な把握は間 隙率を評価することで実現可能であると考えられる。

これまでの間隙率の評価に関する研究を岩石について言及する と，さまざまな方法で岩石の空隙率の測定が試みられている。そ 
れらには, 乾燥・含水飽和状態における重量を秤量する方法 6) や, 水銀圧入式あるいは窒素ガス吸着式のポロシメータによる方法 7) がある。また, 岩石試料の薄片を作成して, 顕微鏡下における観 察から空隙の存在割合を計測する方法もある。ただし, これらの いずれの方法も加熱や液体の圧入, あるいは試料の切断・研磨と いった試料に対する擾乱の影響は無視できない。そこで, Kato et al. ${ }^{8)}$ は, X 線 $\mathrm{CT}^{9)}$ の非破壊・非擾乱の測定法に着目し, X 線 CT 画像から岩石の間隙率の評価を試みた。Kato et al. ${ }^{8)}$ の手法では, 鈗物と空隙の閾值を，4章で後述するミクセルを考慮した対数ゆ う度基準により設定しており，その妥当性について Kato et al. ${ }^{8)}$ は，実際に砂岩を用いた空隙率の評価によって確かめている。

しかし，バイオグラウトのように，供試体内にある間隙水の中 からカルシウム塩が析出して固体となる前後の変化を, 間隙率の 変化として定量的に評価した事例はない。加えて, バイオグラウ 卜供試体内の炭酸カルシウムの析出量はわずかであると考えら れ, 反応後の間隙率の変化はわずかであると考えられるが, この ように反応前後のわずかな間隙率の変化を捉えたいケースにおい ても，ミクセルを考慮した対数ゆう度基準により閾值を選定する 間隙率の評価手法により精度よく評価がおこなわれるかについて は検討がなされていない。

そこで, 本研究では, バイオグラウト供試体を用いて, ミクセ ルを考慮した対数ゆう度基準により閾值を選定する間隙率の評価 手法の有効性を検討した。本研究により，この微小な変化を本手 法で捉えることが可能と評価されれば，それは，それより大きな 変化の把握も可能であることを意味し, 本手法をさまざまな供試 体の間隙率の評価に, 広く適用できるようになると期待できる。 また，本手法では X 線 CT を用いるが，その特長は，供試体内部 の間隙分布および間隙率が 3 次元かつ定量的に評価することがで きる点, さらに，非破壊測定であるため同一の供試体を用いて間 隙分布および間隙率と力学的特性 (強度や変形) との関係を調心 ることができる点である。ただし，本論文では，2 次元かつ供試 体の間隙率のみに着目し，その評価手法に関寸る内容について述 べる。すなわち, 供試体の間隙分布や, 間隙分布および間隙率と 力学的特性との関係については, 別の論文で扱うことにする。

バイオグラウト供試体には, 地盤材料および析出した炭酸カル シウムである「固体」と, その間隙を構成する溶液である「液体」 が含まれる。間隙率を適切に評価するためには，X 線 CT 測定に よって得られる CT 值分布において, 固体と液体の山が分離した 双峰型とならなければならない。部分体積効果 ${ }^{9)}$ を考慮すると, $\mathrm{CT}$ 值分布が双峰型となるかどうかの判断は, 次の 4 つのパラメー タにより決定される。すなわち, (1)溶液の密度, (2)地盤材料の密 度, (3)地盤材料の粒径および(4)ボクセルサイズである。しかし, $\mathrm{X}$ 線 $\mathrm{CT}$ 測定に際してのボクセルサイズには下限值がある。さら に, 溶液の密度を不可変であるとすると, そのようなパラメータ は他の $2 つ$ ( (2)および(3) ) となる。したがって, 本研究ではこれ らを踏まえ, 間隙率の評価を実施する前に予備試験として, CT 值分布が双峰型となる条件を満たすようなさまざまな地盤材料に ついて検討をおこなった。そして, その条件を満たし, 間隙率の 評価が可能であるとされた地盤材料について, 前述した手法で間 隙率を算出し, その有効性を確かめた。

\section{2. 実 験 方 法}

\section{$2 \cdot 1$ 地盤材料の選定試験}

$2 \cdot 1 \cdot 1$ 地盤材料の種類本研究に用いた地盤材料とその 物性を Table 1 に示寸。実際にバイオグラウトの技術を適用する 地盤を想定した, 天然の地盤材料である相馬硅砂 8 号 ( 以下, 硅
Table 1 Properties of geomaterials.

\begin{tabular}{c|c|c}
\hline Geomaterials & Density $\left(\mathrm{g} / \mathrm{cm}^{3}\right)$ & Particle size $(\mathrm{mm})$ \\
\hline Souma sand & 2.65 & $0.1(50 \%$ particle size $)$ \\
\hline Gum tips & 1.15 & 2 \\
\hline Plastic pellets & 1.53 & $\phi 3 \times h 4$ \\
\hline Steel balls & 7.87 & 1.0 \\
\hline Glass beads 1 & 2.50 & $0.105-0.125$ \\
\hline Glass beads 2 & 2.50 & $0.50-0.71$ \\
\hline
\end{tabular}

Table 2 Constituents of grout solution.

\begin{tabular}{c|c}
\hline $1 \mathrm{M}$ Tris- $\mathrm{HCl}$ & $100(\mathrm{ml})$ \\
\hline Glucose & $3.0(\mathrm{~g})$ \\
\hline Calcium nitrate four hydrate & $23.6(\mathrm{~g})$ \\
\hline
\end{tabular}

砂）に加え，パラメータ（密度および粒径）の操作の容易さを考 慮して，人工的な地盤材料すなわちゴムチップ，プラスチックペ レット, スチール球, およびガラスビーズについて検討をおこなっ た。なお, ガラスビーズについては粒径が異なる 2 種類を用い, 粒径の小さな順に, ガラスビーズ 1, 2 とした。

$2 \cdot 1 \cdot 2$ 供試体の作製 本研究では, バイオグラウト供試 体の作製時に使用寸る微生物に関して，入手のしや寸さおよび取 り扱いの容易さを考慮して市販の顆粒状のドライイースト (日清 フーズ株式会社製，日清スーパーカメリア）を用いた。以下，ド ライイーストのことをイースト菌と呼ぶ。また, 溶媒, 有機栄養 源およびカルシウム源として, それぞれ $1 \mathrm{M}$ Tris-HCl, グルコース, 硝酸カルシウム四水和物を用いた。

本試験に用いた供試体の具体的な作製手順を以下に示す。ただ し, 本試験では, 間隙率の評価に適した地盤材料の選定のみを目 的としているため, イースト菌を混入しなかった。

1) Table 2 の配合に従い, $1 \mathrm{M}$ Tris- $\mathrm{HCl}$, グルコース, 硝酸カルシ ウム四水和物を混合した。以下，これをグラウト溶液と呼ぶ。

2) 1)のグラウト溶液を各地盤材料と混ぜ, 空気が混入しないよ うポリスチレン製の容器 (口内径 $12.8 \mathrm{~mm}$, 胴径 $21.0 \mathrm{~mm}$, 高さ $54.8 \mathrm{~mm})$ に入れた。ただし，地盤材料とグラウト溶液の分量は 以下のとおりとした。すなわち, 硅砂以外の各地盤材料につ いては, 地盤材料が容器の $20 \sim 30 \mathrm{~mm}$ の高さまで達するよう に地盤材料の分量を決定し, さらにこれが自重で完全にグラ ウト溶液に浸るようにグラウト溶液の分量を決めた。一方, 硅砂については, グラウト溶液による硅砂の飽和度が $90 \%$ 程 度となり，これらが容器の $20 \sim 30 \mathrm{~mm}$ の高さまで達するよう に硅砂とグラウト溶液の分量を決めた。

$2 \cdot 1 \cdot 3 \quad$ X線 CT 測定 $\quad 2 \cdot 1 \cdot 2$ 項のとおり作製した供 試体を, マイクロフォーカス X 線 CT スキャナ（東芝製， TO SCANER-30900 $\mu \mathrm{hd}$ ) を用いて断層の測定を実施した。測定の際 のスキャンモードは, スライスのシングルとした。また, 分解能 (ボクセルサイズ) は, 本スキャナの下限值である 1 画素サイズ $5 \mu \mathrm{m} \times 5 \mu \mathrm{m}$ およびスライス厚 $16 \mu \mathrm{m}$ とした。さらに，照射 $\mathrm{X}$ 線 の管電圧，管電流はそれぞれ $130 \mathrm{kV}, 62 \mu \mathrm{A}$ とした。

\section{$2 \cdot 2$ 間隙率評価のデータ収集のための試験}

$2 \cdot 2 \cdot 1$ 地盤材料本試験では, 間隙率の変化の評価をお こなうのに十分なデータを収集するため, $2 \cdot 1$ 節の試験で得ら れた CT 值分布が双峰型となり, 間隙率の評価が可能であると判 断された地盤材料を用い, バイオグラウトの処理前後における X 線 CT 測定をおこなった。 
$2 \cdot 2 \cdot 2$ 供試体の作製 バイオグラウトの反応前後にお ける測定の際には，同一の供試体について反応前後を測定するこ とが望ましい。しかし，Mashino et al. ${ }^{10)}$ によると，本研究で使用 する X 線の照射エネルギーにより，供試体内部のイースト菌が 死滅する可能性が高いことが予想された。反応前の供試体の測定 に伴う X 線の照射によりイース卜菌が死滅すると, 以後反応が 進まず反応後の測定結果に影響を与えることとなる。そこで，本 研究では，バイオグラウトの反応前後を測定するための供試体を 別途作製し，反応前後で異なる供試体を測定することにした。以 下，バイオグラウトの反応前，反応後を測定するために作製する 供試体を，それぞれ初期状態供試体，グラウト処理済み供試体と 呼ぶ。グラウト処理済み供試体については,イースト菌を混入し, さらに $25^{\circ} \mathrm{C}$ で 24 時間の静置をおこなった。グラウト処理済み供 試体の作製方法を以下に示す。

1) $2 \cdot 1 \cdot 2$ 項と同様な方法でグラウト溶液を作製した。

2）1）のグラウト溶液に，イースト菌を入れて混ぜた。

3) 2) のグラウト溶液を地盤材料とともに, 空気が混入しないよ うポリスチレン製の容器 (口内径 $12.8 \mathrm{~mm}$ ，胴径 $21.0 \mathrm{~mm}$ ，高さ $54.8 \mathrm{~mm})$ に入れた。ただし，地盤材料とグラウト溶液の分量は $2 \cdot 1 \cdot 2$ 項と同様である。

4) 3) の容器を， $25^{\circ} \mathrm{C}$ に設定したインキュベータに入れ，24 時間 反応させた。

一方，初期状態供試体は，2・1・2 項と同様に作製し，イース 卜菌を混入しなかった。初期状態供試体の作製の際にイース卜菌 を混入しなかったのは，イースト菌混入後から X 線 CT 測定まで の間にイースト菌による反応が進むのを防ぐためである。

また，後に算出する間隙率の信頼性を高める目的で，反応前後 の両供試体とも 3 つずつ作製した。

$2 \cdot 2 \cdot 3 \times$ X線 CT 測定 $2 \cdot 2 \cdot 2$ 項のとおり作製した各供 試体に関して，マイクロフォーカス X 線 CT スキャナを用いて断 層の測定をおこなった。信頼性を高める目的で，各供試体とも下 部から上部まで $5 \mathrm{~mm}$ 間隔で 4 断層を測定した。スキャンモード, 分解能 (ボクセルサイズ ) および照射 X 線の管電圧・管電流は, 2 . $1 \cdot 2$ 項と同様にした。また，ゲイン校正の条件が異なると同一 の被検体でも得られる $\mathrm{CT}$ 值が異なるため, 反応前後の供試体で ゲイン校正の条件を同一とした。

\section{3. 実験結果および考察}

\section{$3 \cdot 1$ 地盤材料の選定試験}

各地盤材料を用いた供試体における，X 線 CT 測定によって得ら れた CT 值分布の形状および間隙率の評価への適性を Table 3 示す。

同表に示寸とおり，得られた CT 值分布が双峰型となったのは， スチール球およびガラスビーズ 2 であった。双峰型の CT 值分布 が得られなかった他の地盤材料については，溶液の密度に対する 地盤材料の密度が小さかったこと，またはボクセルサイズに対す る地盤材料の粒径が小さかったことが，その主たる原因として考 えられる。

一方，双峰型の CT 值分布が得られた 2 つ地盤材料のうち, スチール球に関しては, 再構成画像に X 線 CT 特有のビーム八ー ドニング現象 ${ }^{9)}$ が現れたため, 後の間隙率の評価が適切におこ なうことができないと考えられた。ゆえに，本研究で用いた地盤 材料の中で，間隙率の評価に適した地盤材料はガラスビーズ 2 と なった。したがって,ガラスビーズ 2 を用いた供試体に関しては, 間隙率算出のための詳細なデータ収集を $2 \cdot 2$ 節のとおりおこなっ た。なお, 以後ガラスビーズ 2 のとを単にガラスビーズと呼ぶ こととする。
Table 3 Histogram type and suitability for evaluation of porosity of geomaterials

\begin{tabular}{c|c|c}
\hline Geomaterials & Distribution profile & Suitability for evaluation of porosity \\
\hline Souma sand & Monomodal & $\times$ \\
\hline Gum tips & Monomodal & $\times$ \\
\hline Plastic pellets & Monomodal & $\times$ \\
\hline Steel balls & Bimodal & $\times$ \\
\hline Glass beads 1 & Monomodal & $\times$ \\
\hline Glass beads 2 & Bimodal & $\bigcirc$ \\
\hline
\end{tabular}

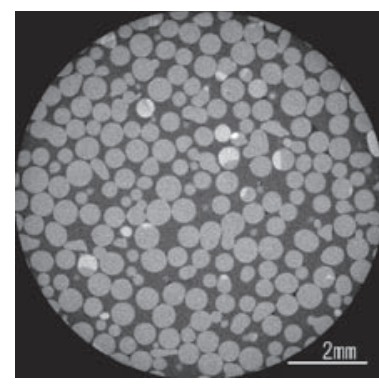

(a) Ungrouted

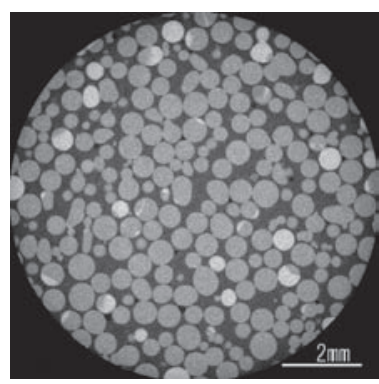

(b) Grouted
Fig.1 X-ray CT images for each specimen of glass beads.

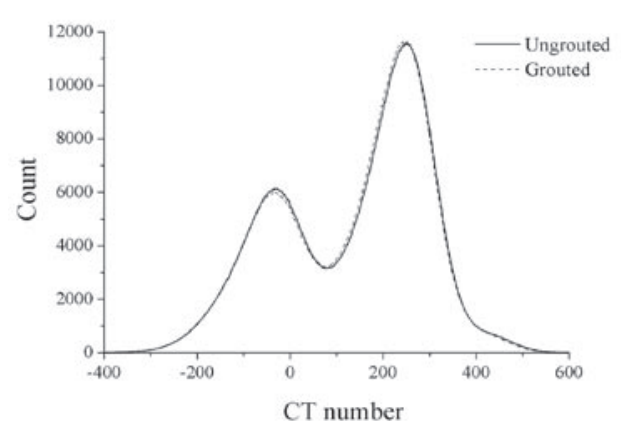

Fig.2 CT number histogram for each specimen of glass beads.

\section{$3 \cdot 2$ 間隙率評価のデータ収集のための試験}

$3 \cdot 2 \cdot 1$ 測定断層画像および CT 值分布 $2 \cdot 2$ 節のとおり, ガラスビーズを用いた供試体の全測定断層数は，バイオグラウト 反応前後で，共に 12 (供試体数 $3 \times$ 断層数 4) である。これらの うち，初期状態およびグラウト処理済办供試体の断層画像の一例 をFig. 1 に示す。同図において, 白色〜明灰色の部分がガラスビー ズを，黒色〜暗灰色の部分が溶液を表している。

また, 測定 12 断層の平均 $\mathrm{CT}$ 值分布を Fig. 2 に示す。地盤材 料は溶液に比して密度が大きいこと，また CT 值は密度に比例す ることから ${ }^{9)}$ ，Fig. 2 における左の山は溶液に，右の山はガラス ビーズにそれぞれ対応している。ここで，気相は溶液に比して密 度が小さいことから，気相の頻度は Fig. 2 における左の山よりも CT 值が小さい領域に現れると考えられる。しかし, Fig. 2 より CT 值分布上にはこの気相を示寸ピークが顕著に現れていないこ とがわかる。したがって, 後の間隙率の評価の際には, 気相の存 在を無視し，供試体内部を固体と液体の二相構造として扱うこと にする。

$3 \cdot 2 \cdot 2$ 信頼性に関する検討 $2 \cdot 2$ 節で前述したとおり， 本研究では, X 線 $\mathrm{CT}$ 測定の際に反応前後で同一の断層を測定す ることができないため, 12 断層を測定し平均をとることでその 信頼性を高めようとした。間隙率の算出をおこなう前に, 本項で は，12 断層の測定により実際にその信頼性が高まったかについ 


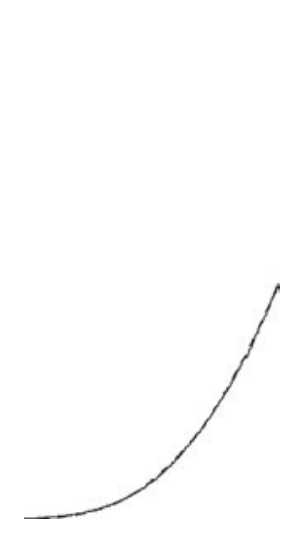

(a) $-350<\mathrm{CT}$ number $<-100$

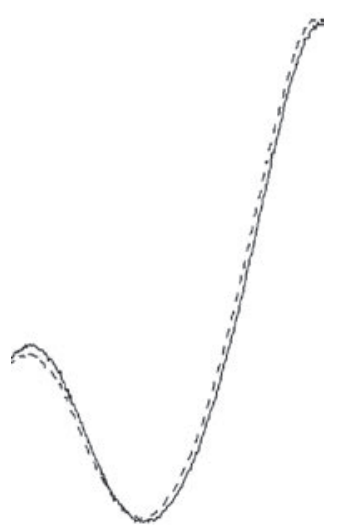

(b) $-50<\mathrm{CT}$ number $<250$

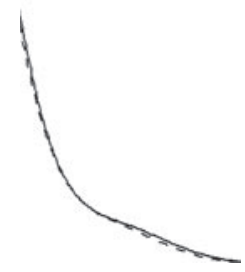

(c) $380<\mathrm{CT}$ number $<550$

Fig.3 Partial enlargements of CT number histogram in Fig.2.

て検討する。

Fig. 2 に示した CT 值分布に関して, 反応前後の変化を視覚的に 把握可能とするために, CT 值が約 $-350 \sim-100,-50 \sim 250$ および 380 ～ 550 の区域を拡大率一定で拡大した図を，それぞれ Fig. 3 の (a)，(b) および (c) に示す。同図 (b) より，CT 值が約 $-50 \sim 250$ の 区域では, 反応前後で $\mathrm{CT}$ 值の頻度の明瞭な変化がみられる。す なわち, 溶液に対応する $\mathrm{CT}$ 值が約 $-50 \sim 80$ の区域では, グラ ウト処理済み供試体の CT 值の頻度が低下し, ガラスビーズに対 応する CT 值が約 $80 \sim 250$ の区域ではグラウト処理済み供試体 の CT 值の頻度が増加していることがわかる。これは，溶液中に 炭酸カルシウムが析出したことによる影響と考えられ，供試体内 で密度上昇が起こったことを示唆するものである。ただし，炭酸 カルシウムの密度は $2.7 \mathrm{~g} / \mathrm{cm}^{3}$ であり, ガラスビーズの密度 2.50 $\mathrm{g} / \mathrm{cm}^{3}$ よりも大きいが，析出した炭酸カルシウムはボクセルサイ ズ以下であったため, 部分体積効果により, 析出した炭酸カルシ ウムの頻度はガラスビーズのピークよりも CT 值の小さい約 80 〜250の区域に分布し，この区域の CT 值分布に影響を与えたと 考えられる。

これに対し，同図 (a) および (c) の CT 值が約 $-350 \sim-100$ およ び380〜550の両区域では, CT 值が約 $80 \sim 250$ の区域に比して 反応前後の変化は小さく, 良い一致を示している。この両区域は, 炭酸カルシウムに対応する CT 值の区域ではなく，それぞれ溶液 およびガラスビーズのみの頻度を表している区域と考えられる。 すなわち, この両区域は炭酸カルシウムの析出が起こったとして も， CT 值の頻度はそれによる影響を受けない区域であると考え られる。

以上のことより, 12 断層の平均の CT 值分布においては, 炭酸 カルシウムの析出による $\mathrm{CT}$ 值の頻度の変化に比して, 断層内の ガラスビーズと溶液の頻度の変化は反応前後で小さく, 一定で あったと考えることができる。なお， 12 断層の平均の CT 值分布 の反応前後における比較を行う前には, 1 断層のみの CT 值分布

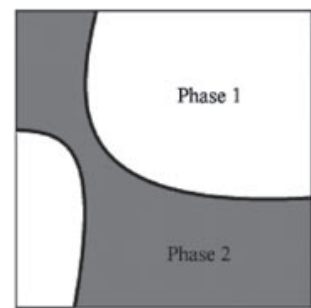

(a) Real image

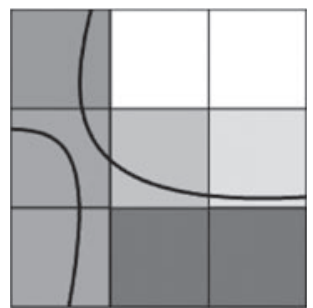

(b) Sampling and quantization image

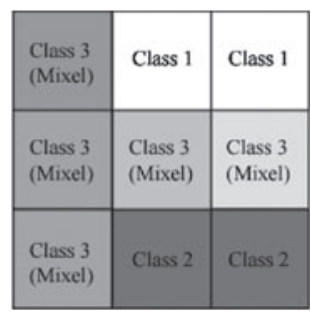

(c) Image

Fig.4 Imaging process of real image.

の比較を行ったが, このときは断層内のガラスビーズと溶液に対 応する $\mathrm{CT}$ 值の頻度は, 良い一致を示さなかった。測定断層数を 12 としたのは, それらが良い一致を示すよう検討を行った結果 である。すなわち, 12 断層の測定により, 断層内のガラスビー ズと溶液の頻度の差は反応前後で小さくなり, 信頼性を高めるこ とができたといえる。ゆえに, 次章の間隙率の評価の際には, こ れら全 12 断層の測定結果を用いて間隙率の評価をおこなう。

\section{4. 間隙率の評価に関する検討}

\section{$4 \cdot 1$ 閾値の設定}

$4 \cdot 1 \cdot 1$ 閾值の設定手法 前述したように, ガラスビーズ を用いたバイオグラウト供試体には, ガラスビーズおよび析出し た炭酸カルシウムである固体と, その間隙を構成する液体が含ま れる。間隙率を適切に評価するためには，X 線 CT 測定によって 得られた双峰型の CT 值分布において, 固体と液体を分ける閾值 の設定が必要である。X 線 CT 画像における閾值の選定に, Kato et al. ${ }^{8)}$ はミクセルを考慮した対数ゆう度基準による手法を用い た。以下では, まず本手法の有効性を述べ, 次にその具体的な選 定プロセスについて概説する。

Fig. 4 は実像を画像化する手順を模式的に示した図である。同 図 (a)の Phase 1, Phase 2 は異なる物質であり, 例えば本研究の 場合には, Phase 1 として液体を, Phase 2 として固体を想定する ことができる。同図のように，連続的な実像に CT 值という離散 的なデジタル值を持たせる場合には，標本化・量子化をおこなう 必要があり,さらにこれを 2 次元の画像として表現する場合には 階調変換が必要となる。実像を標本化・量子化した際, 同図 (b) のように内部に 2 つの物質が混在するボクセルがあるとき, 部分 体積効果により,そのCT 值はそれら 2 つ物質の占有体積によっ て平均化された值となる。そして，そのようなボクセルが階調変 換によって画素に変換されると, 二つの物質に対応する画素 ( 同 図 (c) のクラス 1 およびクラス 2) の值の中間的な值となる。同図 (c)のクラス 3 の画素がそれにあたり, これはミクセル (混合画素, Mixed pixel, Mixel) と呼ばれる 11,12)。これに対し, 同図 (c) のク ラス $1 ， 2$ として示した画素は，もともとその領域内に 1 つの物 質のみしか含んでおらず，それぞれその物質に対応する画素の值 をとる。これらは純粋画素 (Pure pixel) と呼ばれる。クラス 3 の 


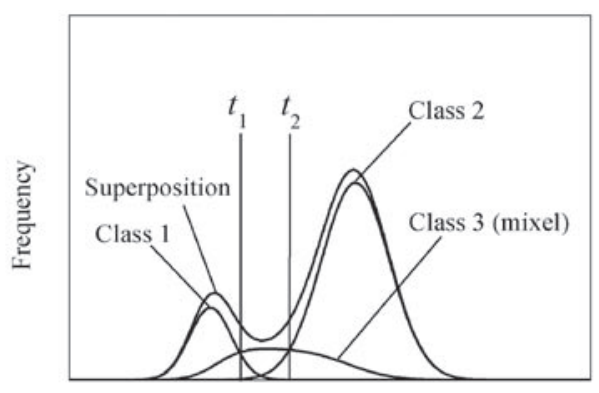

Intensity Level

Fig.5 Concept of threshold setting process.

ミクセルは，処理者の閾值の設定の仕方によって，クラス 1 およ び2の両方に分割される可能性を秘めている。したがって, X 線 CT 画像の閾值設定の際には, ミクセルを考慮し, 処理者の主観 に頼らない一貫した設定手法が重要である。

以上を踏まえて本手法について考えると，本手法では，このミ クセルを考慮した閾值設定をおこなうため，実像を画像化したと きの量子化䛊差を考慮することを可能としているといえる ${ }^{8)}$ 。 さらに, 閾值の算出には対数ゆら度基準を用いており, 処理者の 主観に頼らない一貫した設定を可能としている。以下では，本手 法の具体的な閾值の算出法について述べる。本研究では, クラス 1,2 の CT 值 $x$ の確率密度関数 $p_{i}(x)$ は (1) 式で表される正規分 布に従うものとする。一方, クラス 3 の CT 值 $x$ の確率密度関数 $M(x)$ は (2) 式で与えられるものとする ${ }^{12)}$ 。

$$
\begin{aligned}
& p_{i}(x)=N_{i}\left(x ; \mu_{i}, \sigma_{i}^{2}\right)=\frac{1}{\sqrt{2 \pi \sigma_{i}^{2}}} \exp \left\{-\frac{\left(x_{i}-\mu_{i}\right)^{2}}{2 \sigma_{i}^{2}}\right\} \quad(i=1,2) \cdots \\
& M(x)=\frac{1}{B(m, n)} \int_{0}^{1} a^{m-1}(1-a)^{n-1} N\left(x ; \mu_{a}, \sigma_{a}^{2}\right) d a \ldots \ldots \ldots \ldots . . .
\end{aligned}
$$

ここで, (1) 式の $\mu_{i}, \sigma_{i}{ }^{2}$ はそれぞれ $x$ の平均, 分散を表している。 また, (2) 式の $a$ はクラス 1 の物質の面積占有率であり, ベータ 関数 $B(m, n), M(x)$ の平均 $\mu_{a}$ と分散 $\sigma_{a}^{2}$ は次式 (3) (5) で表さ れる。なお, 本研究では変数 $m, n$ は簡単化のため, $m=1, n=1$ とする。

$$
\begin{aligned}
& B(m, n)=\int_{0}^{1} a^{m-1}(1-a)^{n-1} d a \\
& \mu_{a}=a \mu_{1}+(1-a) \mu_{2} \\
& \sigma_{a}^{2}=a^{2} \sigma_{1}^{2}+(1-a)^{2} \sigma_{2}^{2}
\end{aligned}
$$

例えばいま，密度の異なる 2 つの物質が混在する供試体内部を X 線 CT によって測定し， CT 值の階調変換をおこなって Fig. 5 の Superpositionに示されるような 256 階調の頻度分布が得られ たとする。(1)〜 (5) 式に従えば, これは同図に示されるようにク ラス $1 \sim 3$ の 3 つに分解できる。したがって, これらを分ける䦭 值は 2 つ必要となる。すなわち, 同図に示すクラス 1 とクラス 3 の閾值 $t_{1}$, およびクラス 3 とクラス 2 の閾值 $t_{2}$ である。

以下に，䦐值 $t_{1}$ および $t_{2}$ の算出手順について述べる。

1) 測定によって得られた CT 值に対して階調変換をおこない, 256 階調の画像データへ変換する。

2) 上記の手順 1) のデータを用い, Table 4 にしたがって対数ゆう
Table 4 Correspondence between properties of classes and $\log$ likelihood functions ${ }^{13)}$.

\begin{tabular}{c|c|c|c}
\hline \multicolumn{2}{c|}{} & \multicolumn{2}{|c}{ Variances of each class $\left(\sigma_{k}^{2}\right)$} \\
\cline { 2 - 3 } \multicolumn{2}{c|}{$\begin{array}{c}\text { Occurrence } \\
\text { probability of } \\
\text { each class }\left(\omega_{k}\right)\end{array}$} & nearly equal & different \\
\cline { 2 - 4 } & different & $J_{C}(\mathbf{t})=\ln \frac{1}{\widetilde{\sigma}}$ & $J_{D}(\mathbf{t})=\sum_{k=1}^{M} \widetilde{\omega}_{k} \ln \frac{1}{\widetilde{\sigma}_{k}}$ \\
\hline
\end{tabular}

度 $J_{J}$ が最大となる閾值 $t_{1}$ および $t_{2}$ を選定する。

3）上記の手順 2) において, $t_{1} \fallingdotseq t_{2}$ となった場合には, Table 4 の 対数ゆう度 $J_{D}$ が最大となる間值 $t_{1}$ および $t_{2}$ を選定する。

Table 4 において, $\tilde{\sigma}_{k}$ はクラス $k$ の分散であり, $M$ は総クラス数で, 本研究では $M=3$ である。また, クラス $k$ の生起確率 $\tilde{\omega}_{k}$ と $\tilde{\sigma}^{2}$ は, それぞれ次のように表される。

$$
\begin{aligned}
& \tilde{\omega}_{k}=\frac{\text { クラス } k \text { 存在する画素数 }}{\text { 全画素数 }} . \\
& \tilde{\sigma}^{2}=\sum_{k=1}^{M}\left(\tilde{\omega}_{k} \sigma_{k}^{2}\right)
\end{aligned}
$$

ここで, 上記の手順 2)および3)について,さらに詳しく述べる。 まず, $t_{1}$ および $t_{2}$ をパラメータとしてクラス $k$ の生起確率 $\tilde{\omega}_{k}$ と クラス $k$ の分散 $\tilde{\sigma}_{k}$ 求める。次に, 本研究で扱う分布のクラス の性質を考えると, 各クラスの分散 $\tilde{\sigma}_{k}$ と生起確率 $\tilde{\omega}_{k}$ が両方異な るので, Table 4 の $J_{J}$ を用いるのが望ましい 13,14)。したがって, $\tilde{\sigma}_{k}$ と $\tilde{\omega}_{k}$ の值を $J_{J}$ に代入する。そして, $t_{1}$ および $t_{2}$ を $0<t_{1}$ $<t_{2}<256$ の区域内で変化させ， $J_{J}$ が最大となったときの $t_{1}$ および $t_{2}$ を閾值として選定する。

ただし, $t_{1}$ および $t_{2}$ の局所解に注意が必要である ${ }^{14)}$ 。すなわち, $J_{J}$ 基準での閾值の選定の結果, $t_{1} \fallingdotseq t_{2}$ となることがあるが, こ れは闇值として不適当である。したがって, $t_{1} \fallingdotseq t_{2}$ となったと きには, もう 1 つの対数ゆう度 $J_{D}$ を用いて前述した $J_{J}$ の場合と 同様に閾值 $t_{1}$ および $t_{2}$ を選定し直す必要がある。

$4 \cdot 1 \cdot 2$ 䦭値の設定本研究では, 前述の手法による閾值 の算出を，測定した各断層に対して個別におこなった。測定した 全ての断層は, $J_{J}$ 基準での閾值の選定の結果 $t_{1} \fallingdotseq t_{2}$ となったため, $J_{D}$ 基準により算出した。

本手法による閾值設定の一例として, Fig. 1 (a)に示した断層に おける閾值を，測定頻度分布とともに Fig. 6 に示す。ただし同図 の横軸は, 本手法を適用した際に用いた 256 階調表示であり, $\mathrm{CT}$ 值を階調変換した值である。

\section{$4 \cdot 2$ 間隙率の算出}

$4 \cdot 2 \cdot 1$ 間隙率の算出法 $4 \cdot 1$ 節で算出された閾值から間 隙率を算出する方法について以下に述べる。

各 CT 画像において, 液体の純粋画素をクラス 1, 固体の純粋 画素をクラス 2 とし, また, それらのミクセルをクラス 3 とする。 ミクセルであるクラス 3 の区画には, 標本化・量子化の際に, 液 体および固体の二つの物質が含まれていたことになる。そして, それらがクラス 3 を占有する割合は, 確率論的にそれらの全体に 対する面積占有率に等しい。すなわち, クラス 1 , クラス 2 , ク ラス 3 の面積占有率をそれぞれ $\alpha_{1}, \alpha_{2}, \alpha_{3}$ とすると, クラス 3 はクラス 1 とクラス 2 にそれぞれ $\alpha_{1} \alpha_{3} /\left(\alpha_{1}+\alpha_{2}\right), \alpha_{2} \alpha_{3} /\left(\alpha_{1}+\alpha_{2}\right)$ と分割できる。したがって, 間隙率 $\phi$ は次式のように求められる。

$$
\phi=\frac{\alpha_{1}+\frac{\alpha_{1} \alpha_{3}}{\alpha_{1}+\alpha_{2}}}{\alpha_{1}+\alpha_{2}+\alpha_{3}}=\frac{\alpha_{1}}{\alpha_{1}+\alpha_{2}}
$$




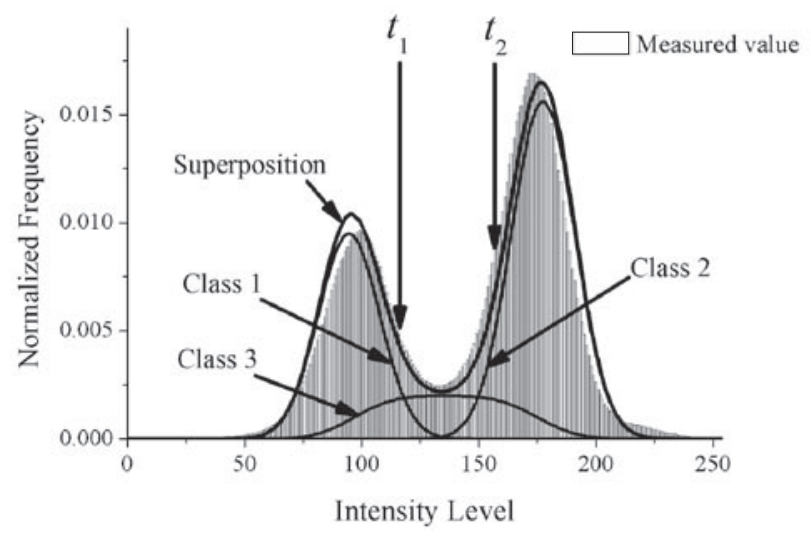

Fig.6 A result of threshold setting.

$4 \cdot 2 \cdot 2$ 間隙率の算出 各クラスの面積占有率は, $4 \cdot 1 \cdot$ 2 項で算出した閾值を用いて, 頻度の積算によって求めた。そし て, 求まった面積占有率を(8) 式に代入し, 各断層における間隙 率を求めた。さらに, その間隙率に関して, 反応前後の供試体で それぞれ 12 断層の平均值を算出した。各クラスの面積占有率お よび間隙率の 12 断層の平均值を Table 5 に示す。ここで, 初期 状態供試体の間隙率の平均值 $\phi_{1}$ に対するグラウト処理済み供試 体の間隙率の平均值 $\phi_{2}$ の比 $\phi_{2} / \phi_{1}$ を求めると次のようになった。

$$
\frac{\phi_{2}}{\phi_{1}}=0.98
$$

このように, $\phi_{2} / \phi_{1}$ の值は 1 未満となり, グラウト処理済み供試 体の間隙率が, 初期状態供試体のそれに比して低下したことが明 らかとなった。一方, $3 \cdot 2 \cdot 2$ 項で前述した Fig. 2 の CT 值分布 においても, 析出した炭酸カルシウムによりグラウト処理済み供 試体における溶液の頻度が相対的に減少し, 固体の頻度が増加し たことから，グラウト処理済み供試体の間隙率が初期状態供試体 のそれに比して低下したことが理解できる。したがって, Fig. 2 の $\mathrm{CT}$ 值分布においてこのように視覚的に把握可能であった間隙 率の変化を, 本手法によって具体的な数值として定量的に捉える ことができたことになる。

\section{$4 \cdot 3$ 推定值の算出と比較}

前節で X 線 CT による測定結果および閾值設定手法から算出し た $\phi_{2} / \phi_{1}$ の值を実測值と呼び, 以下に求める推定值と比較する。 推定值は, バイオグラウト反応前後の溶液中のカルシウムイオン 濃度の変化から試算することができる。初期状態供試体の間隙率 $\phi_{1}$ に対するグラウト処理済み供試体の間隙率 $\phi_{2}$ の比 $\phi_{2} / \phi_{1}$ は次 式で算出される ${ }^{15)}$ 。

$$
\frac{\phi_{2}}{\phi_{1}}=\frac{c y}{27}
$$

ただし， $c$ はカルシウムイオンの初期濃度 $(\mathrm{mol} / \mathrm{l}), y$ は初期状 態のカルシウムイオンが炭酸カルシウムの生成に寄与した割合 ( 以下，反応率）である。

$y$ 值を推定する際には, Shoji5) の研究結果を用いた。Shoji ${ }^{5)} に$ よると, カルシウムイオン濃度 $0.1 \mathrm{~mol} / 1$ および $1 \mathrm{~mol} / 1$ のバイオグ ラウト供試体を $25^{\circ} \mathrm{C}$ で 18 時間および 24 時間静置したときのカ ルシウムイオン濃度の変化は Table 6 のようになる。ただし, 同 表の測定は溶液のみで実施した点に注意が必要である。ここで, 初期のカルシウムイオン濃度を $C_{0}, n$ 時間後のカルシウムイオ
Table 5 Average area occupancies and porosities for each specimen.

\begin{tabular}{c|c|c|c|c}
\hline & \multicolumn{3}{|c|}{ Area occupancy } & \multirow{2}{*}{ Porosity } \\
\cline { 2 - 4 } & Fluid $\left(\alpha_{1}\right)$ & Solid $\left(\alpha_{2}\right)$ & Mixel $\left(\alpha_{3}\right)$ & \\
\hline Ungrouted & 0.295 & 0.551 & 0.154 & 0.349 \\
\hline Grouted & 0.288 & 0.557 & 0.155 & 0.340 \\
\hline
\end{tabular}

Table 6 Changes in concentration of calcium ion with time ${ }^{5)}$.

\begin{tabular}{c|c|c|c}
\hline \multirow{2}{*}{} & \multicolumn{3}{|c}{ Concentration of calcium ion(mol/l) } \\
\cline { 2 - 4 } & Initial state & 18 hours later & 24 hours later \\
\hline Case 1 & 0.1 & 0.03 & 0.05 \\
\hline Case 2 & 1.0 & 0.75 & 0.81 \\
\hline
\end{tabular}

Table 7 Rates of reaction of the cases in Table 6.

\begin{tabular}{c|c|c}
\hline & 18 hours later & 24 hours later \\
\hline Case 1 & 0.70 & 0.50 \\
\hline Case 2 & 0.25 & 0.19 \\
\hline
\end{tabular}

ン濃度を $C_{n}$ とすると, Table 6 における $n$ 時間後の反応率 $y$ は次 式で求められることから, それぞれの反応率は Table 7 のように なる。

$$
y=\frac{C_{0}-C_{n}}{C_{0}}
$$

本研究におけるカルシウムイオンの初期濃度 $c$ は $0.87 \mathrm{~mol} / 1$ で あり, ケース 1 および 2 の中間の值であること, また, Table 6 において 18 時間後に低下したカルシウムイオン濃度が 24 時間後 に増加していることから，y值の推定には，ケース 1 および 2 に おける 18 および 24 時間後の 4 值を用い, $y=0.19 \sim 0.70$ とした。 この $y$ 值を (9) 式に代入して算出された推定值 $\phi_{2} / \phi_{1}$ は, 次のよ うになった。

$$
\frac{\phi_{2}}{\phi_{1}}=0.98 \sim 0.99
$$

以上のように求めた $\phi_{2} / \phi_{1}$ の推定值と, $4 \cdot 2$ 節で求めた実測值 は良い一致を示した。よって, バイオグラウト供試体の間隙率の 変化の評価に, X 線 CT およびミクセルを考慮した対数ゆう度基 準による閾值設定手法を用いた本手法は有効であることがわかっ た。そして, 本手法は, バイオグラウト反応前後における $1 \sim 2 \%$ というわずかな間隙率の変化の評価を適切におこなうことを可能 としたことから, これより大きな間隙率の変化の評価も, 本手法 を用いることで適切におこなうことができることになる。

さらに, 前述のように, 本研究では䦨值の算出を $J_{J}$ 基準では なく $J_{D}$ 基準によっておこなったが，この場合でも閾值の算出が 適切におこなえることがわかった。

\section{5. まとめと今後の課題}

本研究では, まず, $\mathrm{X}$ 線 $\mathrm{CT}$ を用いてバイオグラウト供試体の 間隙率の評価が可能な地盤材料について選定をおこなった。次に, 選定された地盤材料について, ミクセルを考慮した対数ゆう度基 準により閾值を選定する間隙率の評価手法を用い, 反応前後の間 隙率の変化を評価した。本研究を通して得られた知見を以下にま とめる。

1) 本研究で用いた地盤材料の中で, 間隙率の評価が可能と選定

されたのは, 粒径が 0.50-0.71 mm であるガラスビーズであった。 2) 初期状態供試体の間隙率 $\phi_{1}$ に対するグラウト処理済み供試体 
の間隙率 $\phi_{2}$ の比の推定值は $\phi_{2} / \phi_{1}=0.98 \sim 0.99$ であり,一方, $\mathrm{X}$ 線 CT および間隙率の評価における本手法で求めた実測值は $\phi_{2} / \phi_{1}=0.98$ と, 両者は良い一致を示した。よって, バイオグ ラウト供試体の間隙率の算出に本手法が有効であることがわ かった。

今後は，人工的な地盤材料を用いてその粒径および密度を詳細 に変化させ，間隙率の評価の可 / 不可との関係式を求める必要が ある。この関係式が確立されれば，これを用いて天然の地盤材料 の場合も, 間隙率の評価が可能であるかについての判断ができる こととなる。そして，その関係式によって間隙率の評価が可能と された地盤材料については，その地盤材料を含む供試体の間隙率 を本研究で用いた手法で算出することができることとなる。

前述したように，1 章で示したような他の間隙率の評価手法に 比して本手法は，X線 CT 法を用いているため非破壊・非擾乱の 測定が可能であるという特長を持つ。したがって, 例えば間隙率 の変化と強度との関係を把握したい場合においては, 間隙率の測 定と強度試験の両方が必要になるが，間隙率の算出に本手法を用 いれば，間隙率の算出と強度試験で同一の供試体を用いることが できることとなる。バイオグラウト供試体においても，強度の向 上を目指寸にあたり, 間隙率の変化と強度との関係を把握する必 要が今後生じてくる。したがって，そのような場合に本手法を用 いることは意義があると考えられる。
謝辞本研究は, 日本学術振興会科学研究費補助金基盤研究 (B)（課題番号：18300304, 研究代表者：川㠃了）により行われた。 末筆ながらここに記して, 深甚なる感謝の意を表する次第である。

\section{References}

1) S. Kawasaki, A. Murao, N. Hiroyoshi, M. Tsunekawa and K. Kaneko: Jour. Japan Soc. Eng. Geol., 47 (2006) , 2-12.

2) J. T. DeJong, M. B. Fritzges and K. Nusslein: Journal of Geotechnical and Geoenvironmental Engineering, 132 (2006) , 1381-1392.

3) V. S. Whiffin, L. A. van Paassen and M. P. Harkes: Geomicrobiology Journal, 24 (2007), 417-423.

4) K. Kiyota, A. Murakami and S. Kawasaki: Jour. Japan Soc. Eng. Geol., 50 (2009) , $70-78$.

5) H. Shoji: Graduation thesis (2008), Hokkaido University.

6) U. Yamaguchi and Y. Nishimatsu: Ganseki Rikigaku Nyumon, (Tokyo Daigaku Syuppan Kai, Tokyo, 1991), pp.16-18.

7) M. Kawamura and S. Chatterji: Concrete no Zairyo Kagaku, (Morikita Syuppan Kabushiki Kaisya, Tokyo, 2002), pp.77-79.

8) M. Kato, M. Takahashi and K. Kaneko: Geoinformatics, 19 (2008) , 132-133.

9) M. E. Coles: Ch. 8 X-ray imaging, In: Method in the Physics of Porous Media (P.-z. Wong, Ed.), (Academic Press, San Diego, 1999), pp.301-336.

10) Y. Mashino, N. P. Hua, R. Nakai, T. Hasegawa, K. Nakamura, K. Yukimura, T. Naganuma, S. Imura, T. Iwatsuki, K. Kobayashi, M. Saigusa, H. Sato, K. Shimada, Y. Shirakabe, Y Takano, K. Takayama, H. Tawara, H. Hashimoto, Y. Morita, H. Yasuda, M. Yamashita and H. Yoshida: Space Utiliz Res, 24 (2008) , 314-317.

11) A. Kitamoto and M. Takagi: Trans. IEICE, J81-D-II (1998) , 2582-2597.

12) A. Kitamoto and M. Takagi: Trans. IEICE, J81-D-II (1998), 1160-1172.

13) I. Sekita, T. Kurita, N. Otsu and Nabih N. Abdelmalek: Trans. IEICE, J78-D-II (1995), 1806-1812.

14) A. Kitamoto: A maximum likelihood Thresholding methods considering the effect of mixels, PRMU99-166 (1999), 7-14.

15) Y. Kobayashi: Graduation thesis (2009), Hokkaido University. 